\title{
To Heal or Not to Heal? Medicinal Mushrooms Wound Healing Capacities
}

\author{
Waill A. Elkhateeb ${ }^{1 *}$, Marwa O. Elnahas ${ }^{1}$, Paul W. Thomas ${ }^{2,3}$, Ghoson M. Daba ${ }^{1}$ \\ ${ }^{1}$ Chemistry of Natural and Microbial Products Department, Pharmaceutical Industries Researches Division, \\ National Research Centre, El Buhouth St., Dokki, 12311, Giza, Egypt. \\ ${ }^{2}$ Mycorrhizal Systems Ltd, Lancashire, PR25 2SD, UK. \\ ${ }^{3}$ University of Stirling, Stirling, FK9 4LA, UK
}

*Corresponding Author: Waill A. Elkhateeb, Chemistry of Natural and Microbial Products Department, Pharmaceutical Industries Researches Division, National Research Centre, El Buhouth St., Dokki, Giza, Egypt.

\begin{abstract}
Several compounds are responsible for the therapeutic activities of many medicinal mushrooms genera; the main groups of these compounds are polysaccharides, terpenes, phenolic compounds, and essential amino acids, as well as minerals such as such as calcium, potassium, magnesium, iron, and zinc.In this review we focused on the wound healing promoting effect of some medicinal mushrooms of interest including: Handkea utriformis,Hericium erinaceus, Morchella esculenta, Sparassis crispa and Agaricus blazei
\end{abstract}

Keywords: Wound healing; Medicinal Mushrooms; Handkea utriformis; Hericium erinaceus;Morchella esculenta; Sparassis crispa; Agaricus blazei.

\section{INTRODUCTION}

The medicinal properties of mushrooms have been known about for millennia and were exploited for the benefit of humans by many ancient civilizations, including those in Ancient China, Eastern Europe, Mesoamerica and Africa. Mushrooms are known to be medically active in several therapies, such as antitumor, antibacterial, antiviral and other, the therapeutic effect is linked to the presence of bioactive compounds $[\mathbf{1 , 2}]$.

Searching fornovel effective compounds that enhance wound healing is a new interest in the modern biomedical sciences. Nowadays, many researchers focus on the phyto medicine due to the ability of various plants to heal wounds via natural repair pathways. Exceeding $70 \%$ of pharma products for wound healing depend mainly on plants, however, only $20 \%$ of those products depend on mineral compounds $[\mathbf{2 , 3}]$. In this respect, more attention was attracted towards higher fungi that show a vast range of vital therapeutic properties.

However, the ability of mushrooms to heal wounds have not been completely identified. Hence, the study of the effect of mushrooms on wound healing is crucial. In addition, the results depend mainly on the fungus type, its strain, the composition of culture medium for fungus cultivation, the fungus part used in the study (Spores, mycelia, fruit bodies), as well as the methods of its active ingredients production (the medium for suspending, the extractant) [1-3].

Several studies have presented promising wound healing activity of Handkea utriformis,Hericium erinaceus, Morchella esculenta, Sparassis crispa and Agaricus blazei, many of those studies use relatively crude extracts. Further research is required to isolate and identify more bioactive compounds responsible forwound healing activity.

\section{HANDKEA UTRIFORMIS (PUFFBALL)}

Numerous studies showed that many mushrooms are considered a valuable source of many biologically active compounds that may have a great beneficial influence on human health $[2,3]$. 
Since many mushroom species have been used long time ago in traditional medicines, many scientists directed their efforts for the use of these mushrooms in modern medicine.

Handkea utriformis which is known as mosaic puffball is one of the mushroom species that belongs to puffballs mushrooms. This group of mushrooms is characterized by producing globose and enclosed fruiting bodies [4]. When young, $H$. utriformis are edible and characterized by being firm with white color, but when get mature the mushroom fruiting bodies undergoes an autolysis process resulting in changing the mushroom insides (gleba) into a dark mass bearing powdery spores $[5,6]$.

Puffballs have gained an importance for being used as wound dressings as well as a remedy for different skin conditions [6]. This could be attributed to the presence of some biologically active compounds that play vital roles in skin health. These compounds include ergosterol, $\alpha$-tocopherol and GlcNAc thus $H$. utriformis gained an importance as a promising member for both wound healing and several cosmetic products $[8,9]$.

It was reported that $H$. utriformis extract of the fruiting bodies during maturation produces $26 \mathrm{mg} / \mathrm{g}$ of $\mathrm{N}$-acetylglucosamine (GlcNAc) which is an amino sugar and a vital building unit of the fungal chitin polysaccharide due to the chitinolysis process [10].The 13C NMR spectra of $H$. utriformis extract revealed the presence of signals for carbonyl ( $\delta$ 174.54), methyl carbons $(\delta 22.23$ and 21.96) and anomeric carbons ( $\delta 94.99$ and 90.90) which are specific for GlcNAc[11].As GlcNAc plays an important role in the fungi structure, it also showed an important role in the human beings. It is a major building unit of human glycosaminogly can of human connective tissue which is the hyaluronic acid. GlcNAc is a sparked an ingredient in many cosmetics, pharmaceuticals and nutritional supplements as it improves the skin hydration, reparation, and to contribute as anti-wrinkle agent which is attributed to the important role of hyaluronic acid in the skin's integrity and health [7].

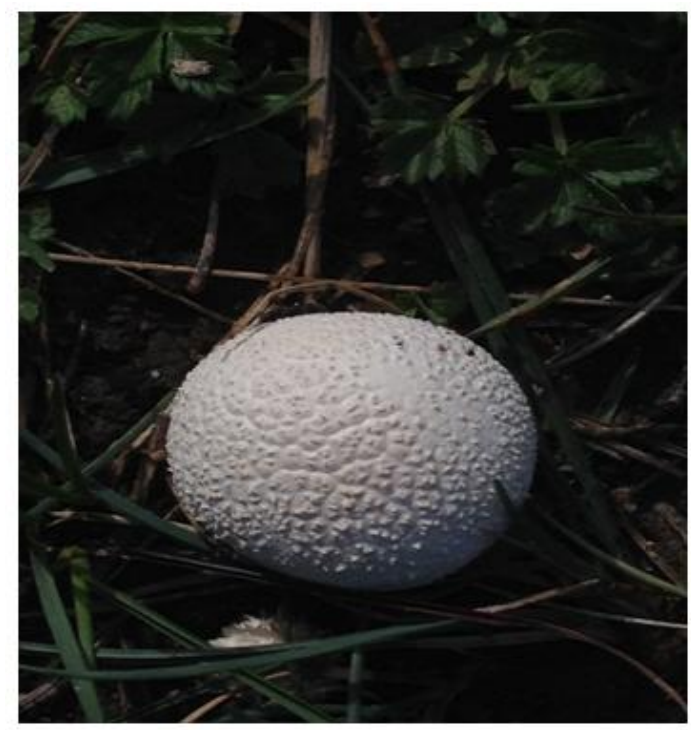

Fig1. Handkea utriformis (Photographs taken by eddi bisulli,Locality: Italy, Trentino-Alto Adige, 38046, Lavarone, Trentino-Alto Adige, IT, hosted by http://mycoportal.org).

\section{HeRICIUM ERINACEUS (LION'S MANE MUSHROOM)}

Hericium erinaceus is an edible, medicinal mushroom of family Herinaceae [12]. H. erinaceus has been known with several names including lion's mane, bearded tooth carpophores and yamabushitake. Various therapeutic importances have been reported for both its fruiting bodies and mycelium. H. erinaceus has been used in the Chinese and Japanese medical systems, where it has been used to nourish the gut, spleen as well as it has been used as an anticancer drug [13].It finds also a great application for the treatment of stomach and duodenal ulcers [14]. Beside its existence in Asia, this species is also found in North America and the northern hemisphere in Europe.

When getting mature, $H$. erinaceus can be easily identified by the presence of conspicuous basidiomes that is formed of numerous single fleshy long spines with white color that turns yellow and finally brown by aging. However, the microscopical examination revealed the presence of amyloidbasidiospores [15]. Hericium basidiomes differentiate from primordia as a single clump; the branches are formed as it grows older [16]. 
Many bioactive compounds have been isolated from $H$. erinaceus, including high molecular weight compounds such as polysaccharides that shows antitumor in vitro, including activity against mammary carcinoma (MCF-7) [17] and malignant hepatocytes (HepG2) [17],or low molecular weight compounds such as terpenoids [19] and polyketides [20].

An interesting study showed that the topical use of $\mathrm{H}$. erinaceus fruiting bodies aqueous extract exhibited a promising wound healing activity. In that study,five groups of male Sprague-Dawley rats were employed to evaluate the wound healing ability of $H$. erinaceus extract. Uniform wound areas of about $2 \mathrm{~cm}$ in diameter each were made in the posterior neck area. This was followed by applying the $H$. erinaceus aqueous extract to the wounds. Sterilized distilled water was used as a negative control while Intrasite gel was used as a positive control. The macroscopical examination results showed that, the rats whose wounds were treated by applying $H$. erinaceus extract dressings and those groups treated with the Intrasite gel- healed much faster than those treated with the negative control (sterilized distilled water). While the histological examination revealed that the wounds that were healed after applying $H$. erinaceus extract contained fewer macrophages and more collagen, also it showed less scar width at wound enclosure comparing to wounds treated with distilled water dressings [21]. These results gave evidence that $H$. erinaceus may be a promising treatment for wound healing.

Another study showed that the aqueous extract of $H$. erinaceus exerted a protective effect toward the gastric mucosa as well as inhibited leucocytes infiltration of gastric wall when the aqueous extract of H. erinaceus was used as a pretreatment in rats with ethanol induced gastric ulcer [22]. It was reported that pretreatment with $H$. erinaceus extract before ethanol administration resulted in a significant reduction in the leucocytes particularly the gastric mucosa neutrophils infiltration which indicates the healing if the gastric ulcer [23,24]. Ethanol administration can damage the gastric mucosa and lead to the increase in the neutrophil infiltration. The neutrophilsare considered a major source of inflammatory mediators which can release reactive oxygen species (ROS) that are cytotoxic and can induce tissue damage [23]. However,the neutrophil infiltration suppression during inflammation process plays a vital role in the healing of the gastric ulcer [25]. Taken together, the aqueous extract of $H$. erinaceus showed an important role in the healing of the gastric ulcer through the suppression of neutrophils infiltration as well as antioxidant activities.

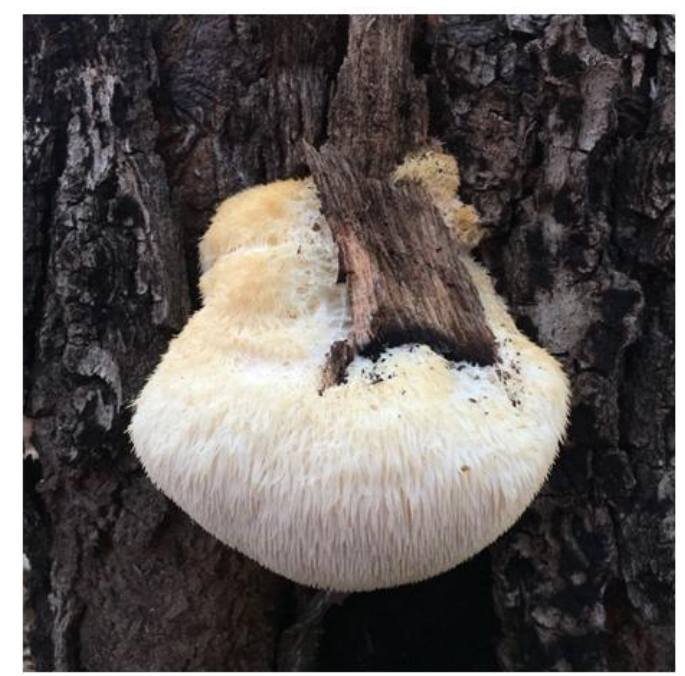

Fig2. Hericium erinaceus (Photographs taken by Patricia R. Miller, USA, Mississippi, Lafayette, North Cypress Trail, Holly Springs National Forest, hosted by http://mycoportal.org).

\section{MORCHELLA ESCULENTA}

Morchella esculenta (L.) Pers. (morel) is one of the most widely appreciated wild edible mushrooms.Morchella esculenta is a highly expensive, edible beneficial wild species of mushroom hence it is called growing gold of mountains, also it is known as guchi, common morel, yellow morel, morel mushroom as well as sponge morel. It is one of the most important and economically beneficial wild species of mushroom. It is commonly found as a mycorrhizal or saprobic relationship with hardwood and coniferous trees. Its growing season is from March to July [26].It grows in cold environments and usually found in coniferous thick forest and humus rich loamy soil with a saprobic or mycorrhizal relationship [27, 28]. 
Morchella esculenta consist of cylindrical structure. The upper part is called as pileus possesses 70$80 \%$ of total plant weight. Its pileus is oval and often globular, yellowish white to yellowish brown in color [29]. Pileus is about 3-9 cm long, $2-5 \mathrm{~cm}$ wide, round or irregular pits are present, it shows yellow, brown, pale or black color.

It contains carbohydrates, proteins, fibres, all important vitamins, minerals and aromatic compounds. Due to its unique flavour, taste and texture it is used in different recipes all over the world. It contains a wide range of pharmacological properties which includes antioxidant, antitumor, antimicrobial and anti-inflammatory properties [30].M. esculenta gains a great importance for its medicinal and nutritional value due to its enrichment with several biologically active compounds such as proteins, dietary fibers, polysaccharides as well as some vital vitamins [30]. These compounds help $M$. esculenta extract to exhibit several important biological activities including antimicrobial properties $[31,32]$, as well as platelet aggregation inhibition. Moreover, the presence of polysaccharides and tocopherols allow its extract to show strong antioxidant and antitumor activity [33, 34]. Interestingly M. esculenta powder exhibited an antiseptic activity which affect positively in wound healing for digestive system symptoms [35].It also acts as an immune stimulant due to the presence of various active constituents. It may be used as purgative, laxative, body tonic, emollient [32] and also used for stomach problems, heal the wound and for general weakness. Due to its high price it plays a very important role in the economy of country.

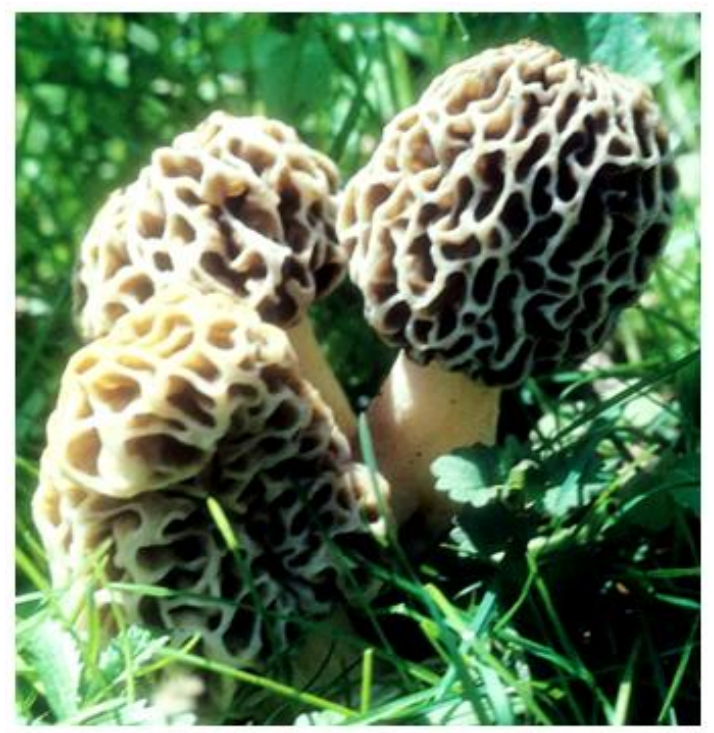

Fig3. Morchella esculenta (Photographs taken by Walt Sturgeon, Locality: USA, Ohio, Columbiana Co., East Livepool,hosted by http://mycoportal.org).

\section{SPARASSiS CRISPA (CAULIFLOWER MUSHROOM)}

Another important edible medicinal mushroom with several medicinal properties is Sparassis crispa. This mushroom belongs to family Sparassidaceae and also known as cauliflower mushroom. Recently it has been very popular in Japan for its medicinal importance [36]. Its occurrence is distributed throughout the North Temperate Zone where it grows on the stumps of coniferous trees a brown rot fungus [36].

Various compounds with human health promoting abilities have been isolated from S. crispa. Its fruiting bodies contain about $90 \%$ water, carbohydrate, protein, lipid, dietary fiber and ash [35].S. crispa has a characterized scent due to the presence of 3-octanone, DL-3-octanol, and 1-octen-3-ol that is contributed to this specific aroma [37].The presence of vitamin D2 that plays vital role in the intestinal calcium absorption was also reported with a concentration that is much higher compared to that found in other mushrooms [38]. A large amount of glucosyl ceramide (nearly $0.2 \%$ ) was also detected in S. crispa extract [36]. And it is important to mention that more than $40 \%$ of the dry weight of $S$. crispa fruiting bodies the beta-glucan [36].

As mentioned before, S. crispa exhibits high medicinal value due to its unique active components. Hot water extracts from $S$. crispa fruiting bodies showed HIV-1 RT inhibitory effect, as it interferes with reverse transcriptase enzyme that is very important for human immunodeficiency virus (HIV) replication [39]. Moreover, Antihypertensive effects for S. crispa was also reported as it delayed the 
occurrence of stroke and death in stroke-prone spontaneously hypertensive rats since it decreased blood pressure and increased blood flow[40].

Regarding the wound healing activity, S. crispa also showed promising activity in diabetic mice where impaired wound healing is a major problem. When rats with streptozotocin- (STZ-) induced diabetes (type 1 diabetes mellitus model) ingested S. crispa for 4 weeks at a dose of $1,000 \mathrm{mg} / \mathrm{kg}$ body weight/day, the wound healing was accelerated [41]. In addition, it was observed a significant increase in the migration of the fibroblast and the macrophage, also an increase in the collagen regeneration was also observed compared to the control groups.

It was noticed that the rate of wound healing in diabetic mice that consume a diet containing about $2.5 \%$ S. crispa was nearly the same as that in diabetic mice after being treated with topical trafermin (fibroblast growth factor formulation). It is noteworthy that the topical application of S. crispa glucan significantly enhanced wound healing in diabetic mice, where the wound contraction ratio was found to be $37 \%$ after 9 days administration, this result that was higher than that of trafermin [42].Hence, the application of $S$. crispa could be extended to the clinical levels, where it may promote wound healing in diabetic patients.

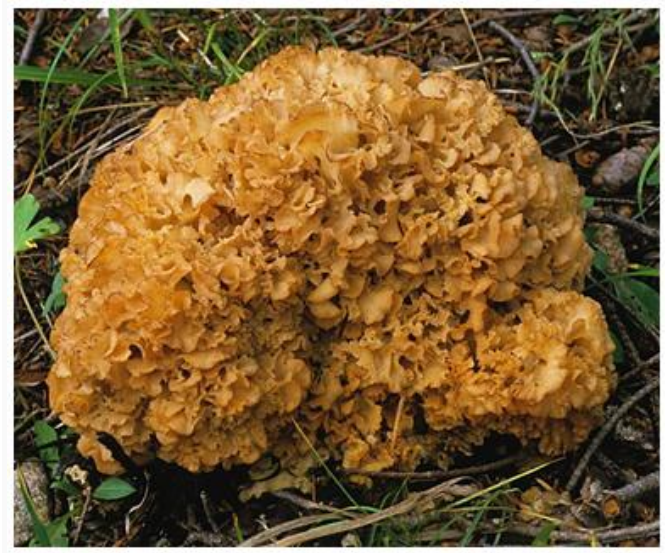

Fig4. Sparassis crispa (Photographs taken by Robert Chapman, Locality: USA, Arizona, Chiricahua Mountains, hosted by http://mycoportal.org).

\section{AGARICUS BLAZEI}

Agaricus blazeiis an edible, basidiomycete fungus that belongs to the Agaricaceae family. It is found in China, Japan and Brazil [43]. A.blazei extracts are able to inhibit the growth of different types of tumor cells in vivo such as including Lewis lung carcinoma, sarcoma-180, Shionogi carcinoma and Ehrlich ascitescarcinoma [44-47].This antitumor activities can be attributed to the induction of apoptosis, restoration of the suppressed host immune system as well as tumor induced neovascularization inhibition[48-50].

As it was known that the burn injury leads to many immune and hence inflammatory dysfunctions. The acute response to burn wounds causes an influx of leukocytes including polymorph nuclear, macrophages and leukocytes to the site of the burn wound [51].The studies proved that the administration of A. blazei polysaccharides was able to increase the wound contraction percentage, indicating the effect of $A$. blazei polysaccharides on rapid collagenization and epithelization. In conclusion, the application of $A$. blazei polysaccharides enhanced the process of burn wound healing after 20 days where polysaccharides ( $100 \mathrm{mg} / \mathrm{kg}$ body weight) resulted in $63.2 \%$ recovery rate [52].

It is relevant to mention the important relation between the skin sensitization potential and the ability of chemicals to alter the expression of the epidermal cytokines. These cytokines include IL-1 which is a molecule found in mouse skin and is expressed by Langerhans cells $[53,55]$. In that study, real-time fluorescent semi quantitative PCR is employed to detect the expressions of IL- $1 \beta$ mRNA exists in the skin sample over 20 days. It was observed that the ratio of IL- $1 \beta / \beta$-act in in model control group increased significantly with $\mathrm{P}<0.01$, on the other hand, the treatment with A. blazei polysaccharides resulted in the decrease of IL- $1 \beta / \beta$-act in ratio in a dose dependent manner [52].

These results indicate that the rats skin burn wound induced the expression of IL-1 $\beta$ mRNA. However, the application of A. blazei polysaccharides in the burn wound site increased the macrophages accumulation which in turn decreased production of IL- $1 \beta$, and this could be the major 
reason for the acceleration of wound healing of A. blazei polysaccharides. Taken together, the results suggest that administration of $A$. blazei polysaccharides may be employed as an effective treatment that enhance the burn wound healing via influencing the immune activity.
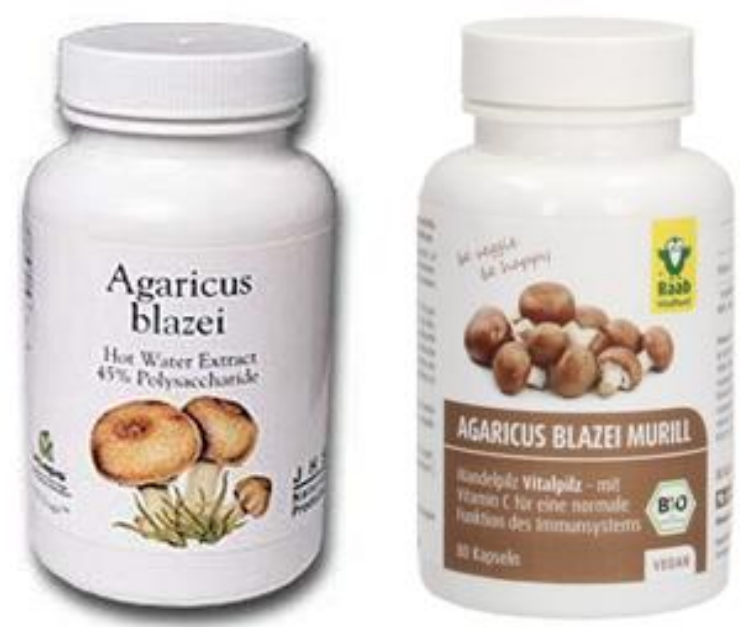

Fig5. Agaricus blazei products: (a) Agaricus blazeipowder capsule (www.amazon.com). (b) Agaricus blazei powder capsule (www.vitalabo.com).

\section{REFERENCES}

[1] Kumarasamyraja D, Jeganathan N, Manavalan R. A review on medicinal plants with potential wound healing activity. International Journal of Pharmacutical Science2012; 2: 105-111.

[2] Elkhateeb WA, Daba GM, Thomas PW, Wen TC. Medicinal mushrooms as a new source of natural therapeutic bioactive compounds. Egyptian Pharmaceutical Journal 2019; 18(2): 88-101.

[3] Lindequist U, Niedermeyer TH, Jülich WD. The pharmacological potential of mushrooms. EvidenceBased Complementary and Alternative Medicine 2005; 2: 285-299.

[4] Larsson E, Jeppson M. Phylogenetic relationships among species and genera of Lycoperdaceae based on ITS and LSU sequence data from north European taxa. Mycological Research 2008; 112: 4-22.

[5] Læssøe T, Spooner B. The uses of 'Gasteromycetes'. Mycologist 1994; 8: 154-159.

[6] Coetze J, van Wyk AE. The genus Calvatia ('Gasteromycetes', Lycoperdaceae): A review of its ethnomycology and biotechnological potential. African Journal of Biotechnology2009; 8.

[7] Pedrali A, Bleve M, Capra P, Jonsson T, Massolini G, Perugini P, Marrubini G. Determination of Nacetylglucosamine in cosmetic formulations and skin test samples by hydrophilic interaction liquid chromatography and UV detection. Journal of pharmaceutical and biomedical analysis2015; 107: 125-130.

[8] Taofiq O, González-Paramás AM, Martins A, Barreiro MF, Ferreira IC. Mushrooms extracts and compounds in cosmetics, cosmeceuticals and nutricosmetics-A review. Industrial Crops and Products2016; 90: 38-48.

[9] Ding J, Kwan P, Ma Z, Iwashina T, Wang J, Shankowsky HA, Tredget EE. Synergistic effect of vitamin D and low concentration of transforming growth factor beta 1, a potential role in dermal wound healing. Burns2016; 42: 1277-1286.

[10] Lim H, Choi, HT. Enhanced expression of chitinase during the autolysis of mushroom in Coprinellus congregatus. The Journal of Microbiology2009; 47: 225-228.

[11] Petrović P, Vunduk J, Klaus A, Carević M, Petković M, Vuković N, Cvetković A, Žižak Ž, Bugarski B. From mycelium to spores: A whole circle of biological potency of mosaic puffball. South African journal of botany2019; 123: 152-160.

[12] Kirk P, Cannon P, Minter D, Stalpers J. Dictionary of the Fungi Wallingford. UK: CABI 2008.

[13] Liu J, Du C, Wang Y, Yu Z. Anti-fatigue activities of polysaccharides extracted from Hericium erinaceus. Experimental and therapeutic medicine2015; 9: 483-487.

[14] Thongbai B, Rapior S, Hyde KD, Wittstein K, Stadler M. Hericium erinaceus, an amazing medicinal mushroom. Mycological Progress2015; 14: 91.

[15] Ginns J. Hericium in North America: cultural characteristics and mating behavior. Canadian journal of botany1985; 63: 1551-1563.

[16] Bernicchia A, Gorjon S. Fungi Europaei: Corticiaceae sl Vol. 12. Alassio: Edizioni Candusso 2010. 
[17] Li Y, Zhang G, Ng TB, Wang H. A novel lectin with antiproliferative and HIV-1 reverse transcriptase inhibitory activities from dried fruiting bodies of the monkey head mushroom Hericium erinaceum. BioMed Research International2010.

[18] Huong LM, Thu HP, Thuy N, Ha T, Thi H, Trang MT, Hang T, Nghi DH, Phuc NX, Quang DT. Preparation and antitumor-promoting activity of curcumin encapsulated by $1,3-\beta$-glucan isolated from Vietnam medicinal mushroom Hericium erinaceum. Chemistry Letters 2011; 40: 846-848.

[19] Shen T, Hof LM, Hausmann H, Stadler M, Zorn H. Development of an enzyme linked immunosorbent assay for detection of cyathane diterpenoids. BMC biotechnology2014; 14: 98.

[20] Wong KH, Sabaratnam V, Naidu M, Keynes R. Activity of aqueous extracts of lion's mane mushroom Hericium erinaceus (Bull.: Fr.) Pers.(Aphyllophoromycetideae) on the neural cell line NG108-15. International Journal of Medicinal Mushrooms2007; 9.

[21] Abdulla MA, Fard AA, Sabaratnam V, Wong KH, Kuppusamy UR, Abdullah N, Ismail S. Potential activity of aqueous extract of culinary-medicinal Lion's Mane mushroom, Hericium erinaceus (Bull.: Fr.) Pers.(Aphyllophoromycetideae) in accelerating wound healing in rats. International journal of medicinal mushrooms2011; 13.

[22] Wong JY, Abdulla MA, Raman J, Phan CW, Kuppusamy UR, Golbabapour S, Sabaratnam V. Gastroprotective effects of Lion's Mane mushroom Hericium erinaceus (Bull.: Fr.) Pers.(Aphyllophoromycetideae) extract against ethanol-induced ulcer in rats. Evidence-Based Complementary and Alternative Medicine 2013.

[23] Cheng C, Koo M. Effects of Centella asiatica on ethanol induced gastric mucosal lesions in rats. Life sciences2000; 67: 2647-2653.

[24] Hariprasath L, Raman J, Nanjian R. Gastroprotective effect of Senecio candicans DC on experimental ulcer models. Journal of ethnopharmacology 2012; 140: 145-150.

[25] Tsukimi Y, Nozue C, Okabe S. Effects of leminoprazole, omeprazole and sucralfate on indomethacininduced delayed healing of kissing gastric ulcers in rats. Journal of gastroenterology and hepatology 1996; 11: 335-340.

[26] Paul N, Slathia P, Vaid A, Kumar R. Traditional Knowledge of Gucchi, Morchella esculenta (Ascomycetes), in Doda District, Jammu and Kashmir, India. International journal of medicinal mushrooms $2018 ; 20$.

[27] Ali H, Sannai J, Sher H, Rashid A. Ethnobotanical profile of some plant resources in Malam Jabba val 2011.

[28] Hamayun M, Khan SA, Ahmad H, Shin DH, Lee IJ. Morel collection and marketing: A case study from the Hindu-Kush mountain region of Swat, Pakistan. Lyonia2006; 11: 7-13.

[29] Bhatt R, Singh U, Uniyal P. Healing mushrooms of Uttarakhand Himalaya, India. Current Research Environ Appl Mycolology2018; 8: 1-23.

[30] Litchfteld J, Vely V, Overbeck R. Nutrient content of morel mushroom mycelium: amino acid composition of the protein. Journal of Food Science 1963; 28: 741-743.

[31] Kalyoncu F, Oskay M, Sağlam H, Erdoğan TF, Tamer AÜ. Antimicrobial and antioxidant activities of mycelia of 10 wild mushroom species. Journal of medicinal food2010; 13: 415-419.

[32] Sher H, Elyemeni M, Sher H, Hussain K. Ethnobotanical and economic observations of some plant resources from the northern parts of Pakistan. Ethnobotany research and applications2011; 9: 027-041.

[33] Heleno SA, Stojković D, Barros L, Glamočlija J, Soković M, Martins A, Queiroz MJ, Ferreira IC. A comparative study of chemical composition, antioxidant and antimicrobial properties of Morchella esculenta (L.) Pers. from Portugal and Serbia. Food Research International2013; 51: 236-243.

[34] Meng F, Zhou B, Lin R, Jia L, Liu X, Deng P, Fan K, Wang G, Wang L, Zhang J. Extraction optimization and in vivo antioxidant activities of exopolysaccharide by Morchella esculenta SO-01. Bioresource technology 2010; 101: 4564-4569.

[35] Mahmood A, Malik RN, Shinwari ZK, Mahmood A. Ethnobotanical survey of plants from Neelum, Azad Jammu and Kashmir, Pakistan. Pakistan Journal of Botany2011; 43: 10.

[36] Kimura T. Natural products and biological activity of the pharmacologically active cauliflower mushroom Sparassis crispa. BioMed research international2013.

[37] Wang Qq, Li Jm, Wang Yq, Zhang Xz, Li Kz. Comparison of aromatic components from Sparassis crispa extracted by Static Headspace and Headspace-SPME. Shipin Gongye Keji2011; 32: 174-176.

[38] Shin HJ, Oh DS, Lee HD, Kang HB, Lee CW, Cha WS. Analysis of Mineral, Amino Acid and Vitamin Contents of Fruiting Body of Sparassis crispa. Journal of Life Science2007; 17: 1290-1293.

[39] Wang J, Wang H, Ng T. A peptide with HIV-1 reverse transcriptase inhibitory activity from the medicinal mushroom Russula paludosa. Peptides2007; 28: 560-565. 
[40] Yoshitomi H, Iwaoka E, Kubo M, Shibata M, Gao M. Beneficial effect of Sparassis crispa on stroke through activation of Akt/eNOS pathway in brain of SHRSP. Journal of natural medicines2011; 65: 135-141.

[41] Kwon AH, Qiu Z, Hashimoto M, Yamamoto K, Kimura T. Effects of medicinal mushroom (Sparassis crispa) on wound healing in streptozotocin-induced diabetic rats. The American Journal of Surgery2009; 197: 503-509.

[42] Yamamoto K, Kimura T. Orally and topically administered Sparassis crispa (Hanabiratake) improved healing of skin wounds in mice with streptozotocin-induced diabetes. Bioscience, biotechnology, and biochemistry 2013; 77: 1303-1305.

[43] Kuroiwa Y, Nishikawa A, Imazawa T, Kanki K, Kitamura Y, Umemura T, Hirose M. Lack of subchronic toxicity of an aqueous extract of Agaricus blazei Murrill in F344 rats. Food and chemical toxicology2005; 43: 1047-1053.

[44] Fujimiya Y, Suzuki Y, Katakura R, Ebina T. Tumor-specific cytocidal and immunopotentiating effects of relatively low molecular weight products derived from the basidiomycete, Agaricus blazei Murill. Anticancer Research 1999; 19: 113-118.

[45] Ito H, Shimura K, Itoh H, Kawade M. Antitumor effects of a new polysaccharide-protein complex (ATOM) prepared from Agaricus blazei (Iwade strain 101)" Himematsutake" and its mechanisms in tumor-bearing mice. Anticancer research 1997; 17: 277-284.

[46] Ohno N, Furukawa M, Miura NN, Adachi Y, Motoi M, Yadomae T. Antitumor $\beta$-glucan from the cultured fruit body of Agaricus blazei. Biological and Pharmaceutical Bulletin2001; 24: 820-828.

[47] Takaku T, Kimura Y, Okuda H. Isolation of an antitumor compound from Agaricus blazei Murill and its mechanism of action. The Journal of nutrition2001; 131: 1409-

[48] Kobayashi H, Yoshida R, Kanada Y, Fukuda Y, Yagyu T, Inagaki K, Kondo T, Kurita N, Suzuki M, Kanayama N. Suppressing effects of daily oral supplementation of beta-glucan extracted from Agaricus blazei Murill on spontaneous and peritoneal disseminated metastasis in mouse model. Journal of cancer research and clinical oncology 2005; 131: 527-538.

[49] Ebina T, Fujimiya Y. Antitumor effect of a peptide-glucan preparation extracted from Agaricus blazei in a double-grafted tumor system in mice. Biotherapy1998; 11: 259-265.

[50] Fujimiya Y, Suzuki Y, Oshiman Ki, Kobori H, Moriguchi K, Nakashima H, Matumoto Y, Takahara S, Ebina T, Katakura, R. Selective tumoricidal effect of soluble proteoglucan extracted from the basidiomycete, Agaricus blazei Murill, mediated via natural killer cell activation and apoptosis. Cancer Immunology, Immunotherapy 1998; 46: 147-159.

[51] Engelhardt E, Toksoy A, Goebeler M, Debus S, Bröcker EB, Gillitzer R. Chemokines IL-8, GRO $\alpha$, MCP1, IP-10, and Mig are sequentially and differentially expressed during phase-specific infiltration of leukocyte subsets in human wound healing. The American journal of pathology1998; 153: 1849-1860.

[52] Sui Z, Yang R, Liu B, Gu T, Zhao Z, Shi D, Chang D. Chemical analysis of Agaricus blazei polysaccharides and effect of the polysaccharides on IL-1 $\beta$ mRNA expression in skin of burn woundtreated rats. International journal of biological macromolecules2010; 47: 155-157.

[53] Muzzarelli RA. Chitins and chitosans for the repair of wounded skin, nerve, cartilage and bone. Carbohydrate polymers2009; 76: 167-182.

[54] Levine JB, Leeder AD, Parekkadan B, Berdichevsky Y, Rauch SL, Smoller JW, Konradi C, Berthiaume F, Yarmush ML. Isolation rearing impairs wound healing and is associated with increased locomotion and decreased immediate early gene expression in the medial prefrontal cortex of juvenile rats. Neuroscience2008; 151: 589-603.

[55] Kasifoglu N, Akgun Y, Sarıcam T, Kiremitci A, Us T. IL-8 serum levels in patients with Helicobacter pylori infection and relation between serological markers. African Journal of Microbiology Research2009; 3: $822-825$.

Citation: Waill A. Elkhateeb, et.al, (2019)." To Heal or Not to Heal? Medicinal Mushrooms Wound Healing Capacities" ARC Journal of Pharmaceutical Sciences (AJPS), 5(4), pp.28-35. DOI: http://dx.doi.org/10.20431/2455-1538.0504004

Copyright: (C) 2019 Authors. This is an open-access article distributed under the terms of the Creative Commons Attribution License, which permits unrestricted use, distribution, and reproduction in any medium, provided the original author and source are credited. 